\title{
MINAT KELUARGA DALAM MELAKSANAKAN PERILAKU HIDUP BERSIH DAN SEHAT (PHBS) RUMAH TANGGA
}

\author{
Nining Istighosah \\ Akademi Kebidanan Dharma Husada Kediri \\ Korespondensi: dealovanining@gmail.com
}

\begin{abstract}
ABSTRAK
Perilaku Hidup Bersih dan Sehat (PHBS) Rumah Tangga adalah upaya untuk memberdayakan anggota rumah tangga agar memahami dan mampu melaksanakan perilaku hidup bersih dan sehat serta berperan aktif dalam gerakan kesehatan di masyarakat. Tujuan penelitian ini adalah untuk meningkatkan minat keluarga dalam melaksanakan perilaku hidup bersih dan sehat (PHBS) rumah tangga. Desain penelitian yang digunakan adalah deskriptif. Populasinya adalah semua keluarga di RT.28/RW.06 Kelurahan Semampir Kecamatan Kota Kota Kediri yang berjumlah 50 KK dan menggunakan teknik Total Sampling yakni semua keluarga yang ada di RT.28/RW.06 Kelurahan Semampir Kecamatan Kota Kota Kediri yang juga berjumlah 50 Responden. Pada penelitian ini hanya terdapat 1 variabel yaitu minat keluarga dalam melaksanakan perilaku hidup bersih dan sehat (PHBS) rumah tangga. Dalam penelitian ini menggunakan kuesioner sebagai instrumen penelitian. Data yang terkumpul diolah (editing, coding, scoring dan tabulating) dan diinterpretasikan dengan skala kualitatif berdasarkan penilaian minat. Minat keluarga dalam melaksanakan perilaku hidup bersih dan sehat (PHBS) rumah tangga 52\% berminat tinggi dan $48 \%$ berminat sedang. Dengan demikian diperlukan KIE (Komunikasi, Informasi, Edukasi) secara tepat oleh tenaga kesehatan mengeai perilaku hidup bersih dan sehat (PHBS) rumah tangga sehingga semua anggota keluarga tahu, mau dan mampu menjalankan perilaku kehidupan yang bersih dan sehat serta memiliki peran yang aktif pada gerakan di tingkat masyarakat
\end{abstract}

Kata kunci : Minat, Keluarga, PHBS Rumah Tangga

\section{PENDAHULUAN}

Masalah kesehatan lingkungan merupakan salah satu dari akibat masih rendahnya tingkat pendidikan, masih terikat eratnya masyarakat dengan adat istiadat, kepercayaan, dan lain sebagainya yang tidak sejalan dengan konsep kesehatan. Perilaku hidup bersih dan sehat merupakan upaya untuk menciptakan suatu kondisi bagi perorangan, keluarga, kelompok dan masyarakat agar dapat menerapkan cara-cara hidup sehat dalam rangka menjaga memelihara dan meningkatkan kesehatan. $^{1,2,3 \text {, }}$

Salah satu misi pembangunan kesehatan di Indonesia adalah menggerakkan dan memberdayakan 
masyarakat untuk berperilaku hidup bersih dan sehat (PHBS). PHBS adalah semua perilaku kesehatan yang dilakukan atas dasar kesadaran sehingga setiap individu dapat menolong dirinya sendiri dalam hal kesehatan dan berperan aktif dalam kegiatan-kegiatan kesehatan di masyarakat. ${ }^{4}$

PHBS yang baik dapat meningkatkan kualitas sumber daya manusia dalam peningkatan derajat kesehatan, status pola gizi dan pemanfaatan sarana kesehatan lingkungan agar tercapai derajat kesehatan yang optimal, sedangkan menurut pusat promosi kesehatan, PHBS dapat mencegah terjadinya penyakit dan melindungi diri dari ancaman penyakit. Dampak perilaku hidup bersih dan sehat (PHBS) yang tidak baik dapat menimbulkan suatu penyakit diantaranya yaitu diare, muntaber, thypus dan demam berdarah. 4-7

Menerapkan PHBS di rumah tangga tentu akan menciptakan keluarga sehat dan mampu meminimalisir masalah kesehatan. Manfaat PHBS di Rumah tangga antara lain, setiap anggota keluarga mampu meningkatkan kesejahteraan dan tidak mudah terkena penyakit, rumah tangga sehat mampu meningkatkan produktifitas anggota rumah tangga dan manfaat phbs rumah tangga selanjutnya adalah anggota keluarga terbiasa untuk menerapkan pola hidup sehat dan anak dpt tumbuh sehat dan tercukupi gizi. ${ }^{5-10}$

Sesuai dengan 10 indikator PHBS pada tingkatan rumah tangga yang dapat dijadikan acuan untuk mengenali keberhasilan dari praktek perilaku hidup bersih dan sehat pada tingkatan rumah tangga yaitu ; Persalinan yang ditolong oleh tenaga kesehatan, Pemberian ASI eksklusif, Menimbang bayi dan balita secara berkala, Cuci tangan dengan sabun dan air bersih, Menggunakan air bersih, Menggunakan jamban sehat, Memberantas jentik nyamuk, Konsumsi buah dan sayur, Melakukan aktivitas fisik setiap hari, dan tidak merokok di dalam rumah. ${ }^{6-10}$

\section{METODE}

Desain penelitian yang digunakan dalam penelitian ini adalah deskriptif. Populasi dalam penelitian ini adalah semua keluarga di RT.28/RW.06 Kelurahan Semampir Kecamatan Kota Kota Kediri yang berjumlah $50 \mathrm{KK}$. Teknik sampling yang digunakan adalah total sampling. Variabel dalam penelitian ini adalah minat keluarga 
dalam melaksanakan perilaku hidup bersih dan sehat (PHBS) rumah tangga. Penelitian ini dilaksanakan pada bulan Agustus 2018. Pengumpulan data pada penelitian ini menggunakan kuesioner minat dengan 4 parameter yaitu; ketertarikan, perhatian, motivasi dan pengetahuan. Hasil prosentase dari skor yang diperoleh untuk pengolahan data setiap variabel diinterpretasikan dengan skala kualitatif meliputi; Tinggi : $67 \%-100 \%$, Sedang : $34 \%-66 \%$, dan Rendah : :0\%-33\%.

\section{HASIL DAN PEMBAHASAN}

a. Karakteristik

Responden

\section{Berdasarkan Umur}

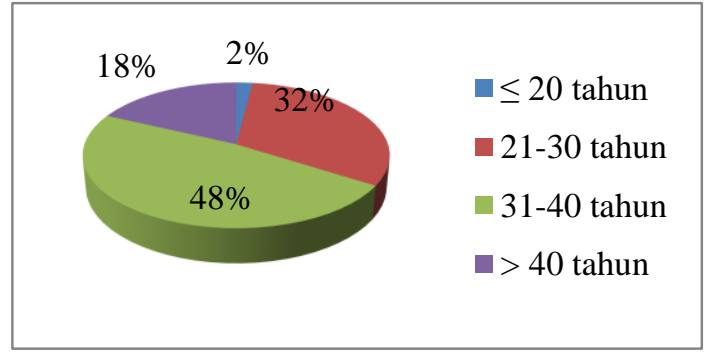

Diagram 1 : Karakteristik responden berdasarkan umur

\section{Berdasarkan} diagram.1

menunjukkan bahwa dari 50 responden mayoritas berumur antara 31-40 tahun yaitu sejumlah 24 orang (48 \%) dan minoritas berumur $\leq 20$ tahun yaitu sejumlah 1 orang $(2 \%)$.

\section{b. Karakteristik Responden} Berdasarkan Pendidikan

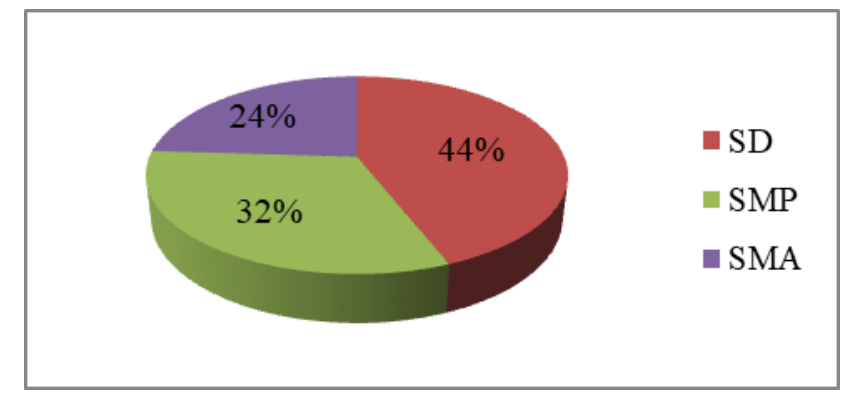

Diagram.2 : Karakteristik responden berdasarkan pendidikan

Berdasarkan diagram.2 menunjukkan bahwa dari 50 responden didapatkan 22 responden $(44 \%)$ berpendidikan terakhir SD dan 12 responden $(24 \%)$ berpendidikan terakhir SMA.

\section{c. Karakteristik Responden}

\section{Berdasarkan Pekerjaan}

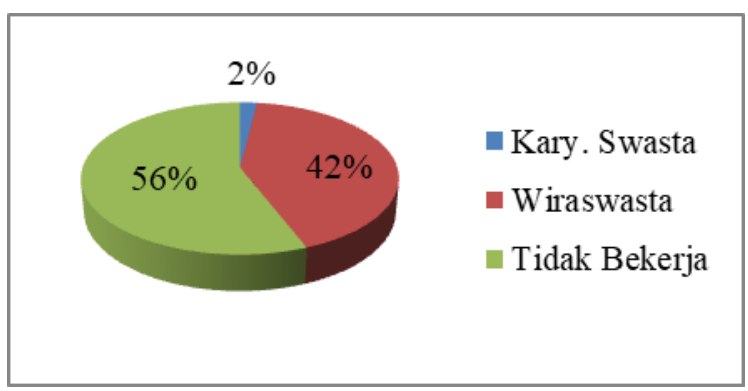

Diagram.3 : Karakteristik responden berdasarkan pekerjaan

Berdasarkan diagram.3 menunjukkan bahwa dari 50 responden didapatkan 28 responden (56\%) tidak bekerja dan 1 responden (2\%) bekerja sebagai karyawan swasta. 


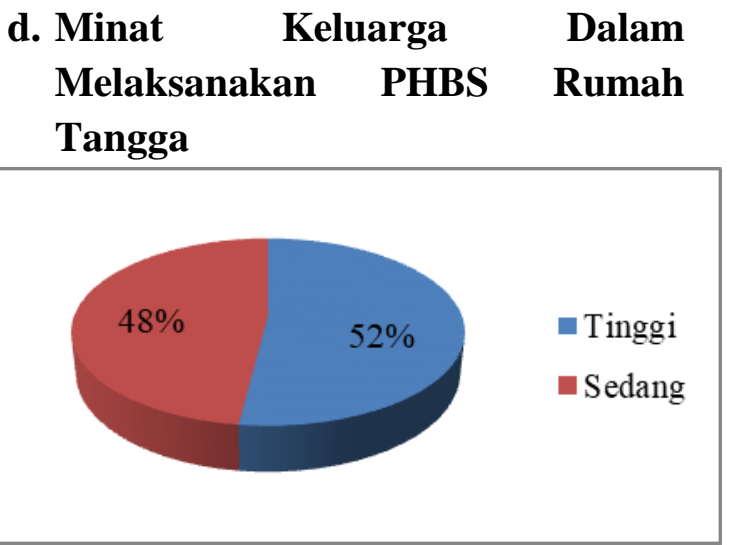

Diagram.4 : Minat keluarga dalam melaksanakan perilaku hidup bersih dan sehat (PHBS) rumah tangga

Berdasarkan diagram $\quad .4$ menunjukkan bahwa dari 50 responden didapatkan 26 responden (52\%) mempunyai minat tinggi dan 24 responden $(48 \%)$ mempunyai minat sedang.

\section{e. Minat}

\section{Keluarga}

Dalam

Melaksanakan PHBS Rumah

Tangga Berdasarkan Ketertarikan

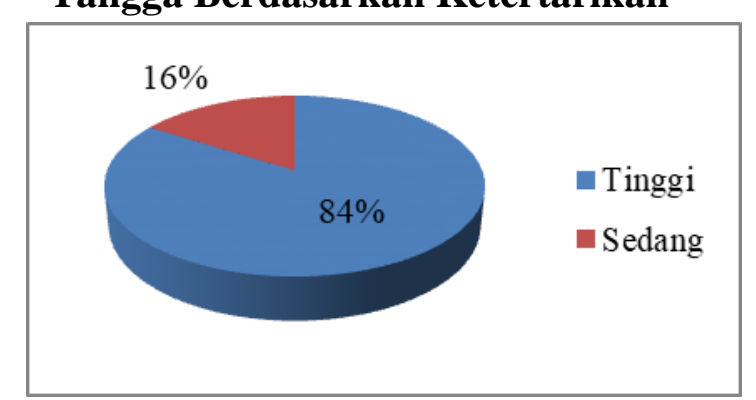

Diagram.5 : Minat keluarga dalam melaksanakan perilaku hidup bersih dan sehat (PHBS) rumah tangga

$$
\text { Berdasarkan diagram.5 }
$$

menunjukkan bahwa dari 50 responden didapatkan 42 responden $(84 \%)$ mempunyai minat berdasarkan ketertarikan dalam kategori tinggi dan 8 responden $(16 \%)$ mempunyai minat berdasarkan ketertarikan dalam kategori sedang.

\section{f. Minat Keluarga Dalam} Melaksanakan PHBS Rumah Tangga Berdasarkan Perhatian

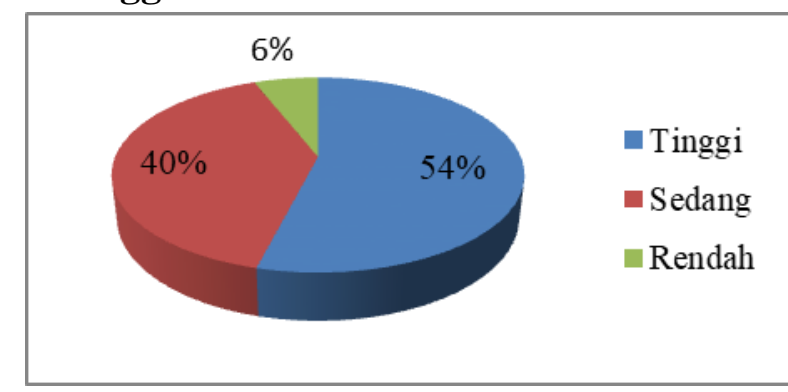

Diagram.6 : Minat keluarga dalam melaksanakan perilaku hidup bersih dan sehat (PHBS) rumah tangga

$$
\text { Berdasarkan diagram.6 }
$$

menunjukkan bahwa dari 50 responden didapatkan 27 responden (54\%) mempunyai minat berdasarkan perhatian dalam kategori tinggi dan 3 responden $(6 \%)$ mempunyai minat berdasarkan perhatian dalam kategori rendah

\section{g. Minat Keluarga Dalam Melaksanakan PHBS Rumah Tangga Berdasarkan Motivasi}

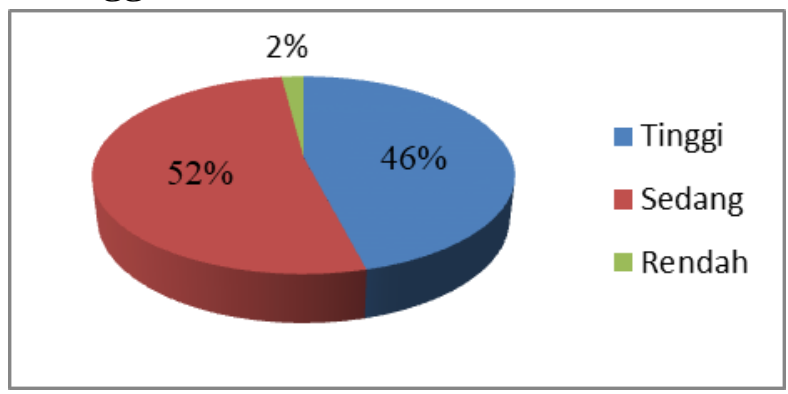

Diagram. 7 : Minat keluarga dalam melaksanakan perilaku hidup bersih dan sehat (PHBS) rumah tangga 
Berdasarkan diagram.7 menunjukkan bahwa dari 50 responden didapatkan 26 responden $(52 \%)$ mempunyai minat berdasarkan motivasi dalam kategori sedang dan 1 responden (2\%) mempunyai minat berdasarkan motivasi dalam kategori rendah.

\section{h. Minat Keluarga Dalam Melaksanakan PHBS Rumah Tangga Berdasarkan Pengetahuan}

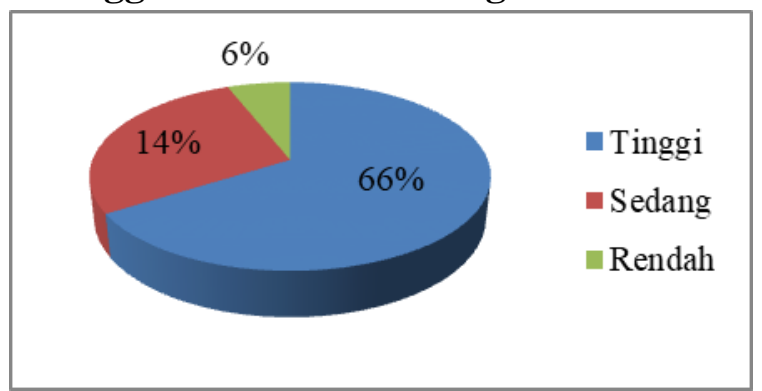

Diagram .8 : Minat keluarga dalam melaksanakan perilaku hidup bersih dan sehat (PHBS) rumah tangga

$$
\text { Berdasarkan diagram.8 }
$$

menunjukkan bahwa dari 50 responden didapatkan 33 responden $(66 \%)$ mempunyai minat berdasarkan pengetahuan dalam kategori tinggi dan 3 responden $(6 \%)$ mempunyai minat berdasarkan pengetahuan dalam kategori rendah.

\section{Minat Keluarga Dalam Melaksanakan PHBS Rumah Tangga}

Berdasarkan hasil penelitian didapatkan bahwa minat untuk melaksanakan perilaku hidup bersih dan sehat (PHBS) rumah tangga dengan kategori tinggi sejumlah 26 responden (52\%) dan kategori sedang sejumlah 24 responden (48 \%). Bila dikaitkan dengan teori, minat ialah suatu dorongan yang menyebabkan terikatnya perhatian individu pada objek tertentu seperti pekerjaan, pelajaran, benda dan orang. (Jahja, 2011 : 63) Menurut Luwzee (2008), minat merupakan gejala psikis yang timbul dari perpaduan keinginan dan kemauan yang ada pada diri seseorang yang direalisasikan atau diekspresikan dengan adanya perasaan senang yang menyebabkan adanya perhatian terbesar terhadap suatu obyek sehingga orang tersebut mempunyai kecenderungan hati untuk berbuat sesuatu terhadap obyek tersebut. Minat dipengaruhi oleh tingkat pendidikan. Makin berpengalaman atau semakin tinggi pendidikan seseorang, maka akan berpengaruh terhadap kematangan dalam berperilaku dan mengambil keputusan dalam suatu masalah, artinya semakin besar pula kegiatan yang bersifat intelek yang dilakukan. (Nursalam dan Pariani, 2001 : 132). Kaitan dengan data umum diatas didapatkan mayoritas responden berpendidikan terakhir SD yaitu sejumlah 22 responden (44\%). Namun hal ini tidak berlaku pada keadaan 
responden dalam penelitian kali ini. Meskipun mayoritas responden berpendidikan terakhir $\mathrm{SD}$, namun responden mempunyai minat tinggi untuk melaksanakan perilaku hidup bersih dan sehat (PHBS) rumah tangga. Hal ini karena atas dasar kesadaran dan kepedulian anggota rumah tangga atau keluarga akan pentingnya hidup bersih dan sehat agar dapat menolong dirinya sendiri dalam hal kesehatan dan mencegah timbulnya penyakit yang dapat menyerang setiap anggota rumah tangga.

Berdasarkan pernyataan diatas, dapat ditelaah kembali bahwa minat tersebut dapat timbul didahului oleh pengetahuan dan informasi, kemudian disertai dengan rasa senang dan timbul perhatian terhadapnya serta ada hasrat dan keinginan untuk melakukannya.

Berbicara mengenai informasi, pada dasarnya setiap keluarga sudah pernah mendapatkan informasi mengenai pentingnya perilaku hidup bersih dan sehat (PHBS) rumah tangga dan merupakan kewajiban semua anggota rumah tangga untuk berperilaku hidup bersih dan sehat pada lingkungan rumah untuk mencegah timbulnya kuman penyebab penyakit.
Minat juga dipengaruhi oleh pekerjaan atau status ekonomi. Berdasarkan diagram 3 menunjukkan bahwa dari 50 responden didapatkan 28 responden $(56 \%)$ tidak bekerja. Jika status ekonomi membaik, orang cenderung memperluas minat mereka untuk mencakup hal yang semula belum mereka laksanakan. Sebaliknya jika status ekonomi mengalami kemunduran karena tanggung jawab dan tata usaha yang kurang maju, maka orang cenderung untuk mempersempit minat mereka. (Nursalam dan Pariani, 2001 : 133). Namun sepertinya hal ini tidak berlaku pada keadaan responden dalam penelitian ini. Responden yang tidak bekerja, secara tidak langsung menunjukkan bahwa status ekonomi mereka memburuk namun responden justru menunjukkan berminat tinggi dalam melakukan perilaku hidup bersih dan sehat (PHBS) rumah tangga karena kesadaran mereka yang memperdulikan akan pentingnya lingkungan yang bersih dan sehat di lingkungan rumah agar setiap anggota keluarga menjadi sehat dan tidak mudah sakit. Kesadaran responden untuk mau melakukan hal yang positif maka akan memudahkan tenaga kesehatan dan Lembaga Swadaya Masyarakat (LSM) untuk 
membiasakan melaksanakan perilaku hidup bersih dan sehat (PHBS) kepada masyarakat, dengan demikian akan menjadikan keluarga yang merasakan manfaat pelaksanaan perilaku hidup bersih dan sehat (PHBS) rumah tangga untuk menjaga kesehatan anggota rumah tangganya, dan yang paling penting adalah para keluarga tahu, tertarik, sadar dan mau melaksanakannya pada lingkungan rumah tangga mereka masing-masing. Sebaliknya pada responden yang bekerja sebagai wiraswasta, secara tidak langsung menunjukkan bahwa status ekonomi mereka lebih baik dibandingkan yang tidak bekerja, justru menunjukkan berminat sedang dalam melaksanakan perilaku hidup bersih dan sehat (PHBS) rumah tangga. Dengan alasan karena kurang adanya waktu untuk melaksanakan perilaku hidup bersih dan sehat (PHBS) rumah tangga dan sebagainya.

Minat juga dipengaruhi oleh faktor umur. Berdasarkan hasil penelitian menunjukkan bahwa dari 50 responden mayoritas berumur antara 3140 tahun yaitu sejumlah 24 orang (48\%). Usia adalah umur individu yang terhitung mulai saat dilahirkan sampai saat berulang tahun. Semakin cukup umur, tingkat kematangan dan kekuatan seseorang akan lebih matang dalam berfikir dan bekerja. Makin tua umur seseorang makin konstruktif dalam mengambil suatu keputusan terhadap masalah yang dihadapi. Makin muda umur seseorang maka akan sangan mengalami konsep diri seseorang. (Nursalam dan Pariani, 2001 : 134) Bila dikaitkan dengan hasil penelitian, sepertinya hal ini berlaku pada keadaan responden dalam penelitian kali ini. Responden yang berumur 31-40 tahun justru menunjukkan berminat tinggi dalam melaksanakan perilaku hidup bersih dan sehat (PHBS) rumah tangga dibandingkan dengan responden yang berumur lebih muda.

Timbulnya minat dipengaruhi oleh dorongan dari dalam. Minat yang berasal dari dalam timbul bila setiap anggota rumah tangga ingin menciptakan lingkungan rumah yang bersih dan sehat untuk mencegah timbulnya kuman penyebab penyakit. Minat dapat berasal dari motif sosial (dorongan dari orang lain) misalnya dukungan dan pembinaan secara rutin dari tenaga kesehatan dan dari Lembaga Swadaya Masyarakat (LSM) kepada semua anggota keluarga. Untuk itu petugas kesehatan mempunyai peran 
penting untuk meningkatkan minat melaksanakan perilaku hidup bersih dan sehat (PHBS) rumah tangga. Anggota keluarga juga diharapkan lebih berperan aktif dalam melaksanakan perilaku hidup bersih dan sehat (PHBS) rumah tangga untuk menghindari adanya kuman penyebab penyakit.

Berdasarkan beberapa fakta dan teori diatas, sebenarnya mempunyai prinsip yang sama bahwa untuk mengubah minat seseorang langkah awal yang harus dilakukan adalah membuat seseorang tersebut menjadi tahu, sadar dan mengerti. Informasi adalah berita tentang sesuatu hal yang diperoleh seseorang. Informasi yang diperoleh dari berbagai sumber akan mempengaruhi tingkat minat seseorang. Semakin banyak informasi yang diperoleh seseorang maka semakin luas pula pengetahuan seseorang tersebut sehingga minat seseorang akan semakin bertambah untuk melakukan sesuatu dengan pertimbangan informasi yang diterimanya. Dan dengan diberikannya informasi atau pendidikan tersebut, akan menambah minat seseorang.

\section{Ketertarikan Rumah Tangga Terhadap PHBS}

Berdasarkan hasil penelitian didapatkan bahwa minat untuk melaksanakan perilaku hidup bersih dan sehat (PHBS) rumah tangga berdasarkan ketertarikan dengan kategori tinggi sejumlah 42 responden $(84 \%)$ dan kategori sedang sejumlah 8 responden $(16 \%)$.

Bila dikaitkan dengan teori, minat ialah suatu dorongan yang menyebabkan terikatnya perhatian individu pada objek tertentu seperti pekerjaan, pelajaran, benda dan orang. Salah satu indikator minat yaitu ketertarikan. Seseorang yang berminat terhadap suatu obyek, maka ia akan memiliki perasaan tertarik terhadap obyek tersebut.

Bila dikaitkan dengan hasil penelitian, hal ini sesuai dengan kondisi responden pada penelitian kali ini. Sebagian besar responden mempunyai minat dalam kategori tinggi untuk melaksanakan perilaku hidup bersih dan sehat (PHBS) rumah tangga yaitu sejumlah 26 responden (52\%). Sedangkan berdasarkan indikator ketertarikan, responden juga mempunyai ketertarikan dalam kategori tinggi untuk melaksanakan perilaku hidup bersih dan sehat (PHBS) rumah tangga yaitu sejumlah 42 responden (84\%). 
Berdasarkan pernyataan diatas, dapat ditelaah kembali bahwa jika seseorang mempunyai minat untuk melaksanakan perilaku hidup bersih dan sehat (PHBS) rumah tangga, maka ia juga akan memiliki perasaan tertarik untuk melaksanakan perilaku hidup bersih dan sehat (PHBS) rumah tangga.

\section{Perhatian Rumah Tangga Terhadap PHBS}

Berdasarkan hasil penelitian didapatkan bahwa minat untuk melaksanakan perilaku hidup bersih dan sehat (PHBS) rumah tangga berdasarkan perhatian dengan kategori tinggi sejumlah 27 responden (54\%), kategori sedang sejumlah 20 responden (40\%) dan kategori rendah sejumlah 3 responden $(6 \%)$. Bila dikaitkan dengan teori, perhatian merupakan konsentrasi atau aktifitas jiwa seseorang terhadap pengamatan, pengertian ataupun yang lainnya dengan mengesampingkan hal lain daripada itu. Menurut Luwzee (2008), minat merupakan gejala psikis yang timbul dari perpaduan keinginan dan kemauan yang ada pada diri seseorang yang direalisasikan atau diekspresikan dengan adanya perasaan senang yang menyebabkan adanya perhatian terbesar terhadap suatu obyek sehingga orang tersebut mempunyai kecenderungan hati untuk berbuat sesuatu terhadap obyek tersebut.

Berdasarkan teori diatas sesuai dengan keadaan responden dalam penelitian. Mayoritas responden memiliki minat dalam kategori tinggi untuk melaksanakan perilaku hidup bersih dan sehat (PHBS) rumah tangga yaitu sejumlah 26 responden (52\%). Sedangkan berdasarkan indikator perhatian, responden juga mempunyai perhatian dalam kategori tinggi untuk melaksanakan perilaku hidup bersih dan sehat (PHBS) rumah tangga yaitu sejumlah 27 responden (54\%).

Hal ini berarti, keadaan responden sesuai dengan terori yang ada. Jika seseorang telah mempunyai minat untuk melakukan sesuatu, maka seseorang tersebut juga akan mempunyai perhatian terhadap suatu objek tersebut.

\section{Motivasi Rumah Tangga Dalam Implementasi PHBS}

Berdasarkan hasil penelitian didapatkan bahwa minat untuk melaksanakan perilaku hidup bersih dan sehat (PHBS) rumah tangga berdasarkan motivasi dengan kategori sedang sejumlah 26 responden (52\%), kategori tinggi sejumlah 23 responden (46\%) dan kategori rendah sejumlah 1 responden $(2 \%)$. 
Bila dikaitkan dengan teori, minat ialah suatu dorongan yang menyebabkan terikatnya perhatian individu pada objek tertentu seperti pekerjaan, pelajaran, benda dan orang. Motivasi merupakan salah satu indikator minat. Minat merupakan suatu usaha atau pendorong yang dilakukan secara sadar untuk melakukan suatu tindakan dan mewujudkan perilaku yang terarah demi pencapaian tujuan yang diharapkan dalam situasi interaksi. Motivasi ialah suatu keadaan dalam diri individu yang mendorong perilaku ke arah tujuan yang diharapkan. Motivasi dapat timbul karena stimulus internal, eksternal maupun interaksi atara keduanya.

Bila dikaitkan dengan hasil penelitian, hal ini tidak berlaku pada keadaan responden pada penelitian. Meskipun responden mempunyai minat dalam kategori tinggi untuk melaksanakan perilaku hidup bersih dan sehat (PHBS) rumah tangga, namun responden mempunyai motivasi dalam kategori sedang. Hal ini berarti, diperlukan peran lintas sektor dan lintas program serta bagian sanitasi untuk memberikan informasi tambahan tentang perilaku hidup bersih dan sehat (PHBS) serta memberikan motivasi agar para anggota rumah tangga terdorong untuk melaksanakan perilaku hidup bersih dan sehat (PHBS) rumah tangga agar terhindar dari kuman penyebab penyakit. Informasi tambahan dan motivasi tersebut akan meningkatkan minat anggota rumah tangga untuk melaksanakan perilaku hidup bersih dan sehat (PHBS) rumah tangga.

\section{Pengetahuan Rumah Tangga Terhadap PHBS}

Berdasarkan hasil penelitian didapatkan bahwa minat untuk melaksanakan perilaku hidup bersih dan sehat (PHBS) rumah tangga berdasarkan pengetahuan dengan kategori tinggi sejumlah 33 responden (66\%), kategori sedang sejumlah 14 responden (28\%) dan kategori rendah sejumlah 3 responden (6\%).

Bila dikaitkan dengan teori, minat ialah suatu dorongan yang menyebabkan terikatnya perhatian individu pada obyek tertentu seperti pekerjaan, pelajaran, benda dan orang. Menurut Luwzee (2008), minat merupakan gejala psikis yang timbul dari perpaduan keinginan dan kemauan yang ada pada diri seseorang yang direalisasikan atau diekspresikan dengan adanya perasaan senang yang menyebabkan adanya perhatian terbesar 
terhadap suatu obyek sehingga orang tersebut mempunyai kecenderungan hati untuk berbuat sesuatu terhadap obyek tersebut.

Berbicara mengenai pengetahuan, selain dari perasaan senang dan perhatian, untuk mengetahui berminat atau tidaknya seseorang terhadap suatu obyek dapat dilihat dari pengetahuan yang dimilikinya. Pengetahuan (knowledge) adalah hasil tahu dari manusia, yang hanya digunakan untuk menjawab pertanyaan.

Bila dikaitkan dengan hasil penelitian, antara teori dan kenyataan bahwa sebagian besar (66\%) adalah responden memiliki pengetahuan dalam kategori tinggi yang pada umumnya juga memiliki minat dalam kategori tinggi. Jadi dapat disimpulkan bahwa makin tinggi tingkat pengetahuan responden tentang perilaku hidup bersih dan sehat (PHBS) rumah tangga, maka makin tinggi pula minat responden untuk melaksanakan perilaku hidup bersih dan sehat (PHBS) rumah tangga. Sehingga, pengetahuan dapat digunakan sebagai dasar untuk menambah informasi dan wawasan kepada responden yang pengetahuannya tentang perilaku hidup bersih dan sehat (PHBS) rumah tangga masih rendah.

\section{SIMPULAN}

Perilaku hidup bersih dan sehat yang berasal dari implementasi materi PHBS dapat menjadi kunci untuk meningkatkan kualitas kesehatan masyarakat. Menjalankan praktek indikator - indikator PHBS di berbagai tatanan dapat menjadi sebuah gerakan untuk memasyarakatkan perilaku hidup bersih dan sehat dimanapun dan juga kapanpun. Berdasarkan hasil penelitian ini dapat disimpulkan bahwa, KIE (Komunikasi, Informasi, Edukasi) secara tepat oleh tenaga kesehatan mengenai perilaku hidup bersih dan sehat (PHBS) rumah tangga sangat diperlukan sehingga semua anggota keluarga tahu, mau dan mampu menjalankan perilaku kehidupan yang bersih dan sehat serta memiliki peran yang aktif pada gerakan di tingkat masyarakat.

\section{UCAPAN TERIMAKASIH}

Pada kesempatan ini peneliti mengucapkan rasa terimakasih kepada seluruh pihak yang terlibat dalam penelitian ini khususnya Akademi kebidanan Dharma Husada Kediri tempat peneliti bekerja. 


\section{DAFTAR PUSTAKA}

1. Pusat Promosi Kesehatan. 2006. Perilaku Hidup Bersih dan Sehat di Rumah Tangga. Depkes RI. 2008. Rumah Tangga sehat Dengan Perilaku Hidup Bersih dan Sehat. Depkes RI.

3. 2009. Peningkatan

Perilaku Hidup Bersih dan Sehat di Rumah Tangga. Depkes RI

4. Sudayasa. 2009. 10 Indikator PHBS Tatanan Rumah Tangga. [Internet] $15^{\text {th }}$ Nov. Available from : (http://www.puskel.com) [Accessed $6^{\text {th }}$ June 2018].

5. Sinaga, Marhaeni, Hasanbasri. 2005. Program Perilaku Hidup Bersih dan Sehat (Studi Kasus Kabupaten Bantul 2003). Jurnal Manajemen Pelayanan Kesehatan (JMPK) Vol. 08 No.2: 9198.

6. World Health Organization (WHO). 2014. Trends in Maternal Mortality. Geneva: World Health Organization.Dinkes Jabar. 2005. Dampak PHBS Yang Tidak Baik. [Internet] $10^{\text {th }}$ April. Available from : (http://www.dinkes.jabarprov.go.id)

[Accessed $6^{\text {th }}$ June 2018].

7. Taufiq, M., Nyorong, M., Riskiyani, S. 2013. Gambaran Perilaku Hidup Bersih dan Sehat (PHBS) Masyarakat di Kelurahan Parangloe Kecamatan Tamalanrea Kota Makassar. Jurnal Media Kesehatan Masyarakat Indonesia

8. Sari, I.I.K. 2015. Peran Promosi Kesehatan di Puskesmas Dalam Capaian Rumah Tangga Dengan Ibu Nifas. Skripsi. Surabaya, Universitas Airlangga

9. World Health Organization, Health and Walfare Canada, Canadian Public Health Association. 1986. Ottawa Charter For Health Promotion. An International Conference on Health Promotion: Canada.

10. Hidayat, A. Aziz Alimul. 2010. Metode Penelitian Kebidanan \& Teknik Analisis Data. Jakarta : Salemba Medika
11. Jahja, Yudrik. 2011. Psikologi Perkembangan. Edisi I. Jakarta : Kencana.

12. Mubarak dkk. 2010. Ilmu Keperawatan Komunitas, Konsep dan Aplikasi. Jilid 2. Jakarta : Salemba Medika.

13. Notoadmodjo, Soekidjo. 2002. Metodologi Penelitian Kesehatan. Jakarta : Rineka Cipta.

14. 2007. Kesehatan Masyarakat Ilmu dan Seni. Jakarta : Rineka Cipta.

15. . 2010. Metodologi Penelitian Kesehatan. Jakarta : Rineka Cipta.

16. Nursalam. 2009. Konsep dan Penerapan Metodologi Penelitian Ilmu Keperawatan. Edisi II. Jakarta : Salemba Medika.

17. Sugiyono. 2007. Statistika Untuk Penelitian. Bandung: Alfabeta.

18. Ajzen. 2010. Cara Mengukur Minat. [Internet] $18^{\text {th }}$ March. Available from : (http://creasoft.wordpress.com) [Accessed 21 ${ }^{\text {th }}$ June 2018]. 